\title{
Evolution of extreme temperatures over Portugal: recent changes and future scenarios
}

\author{
Alexandre M. $\operatorname{Ramos}^{1,2, *}$, Ricardo M. Trigo ${ }^{2,3}$, Fátima E. Santo ${ }^{4}$ \\ ${ }^{1}$ Environmental Physics Laboratory, Universidad de Vigo, Facultad de Ciencias de Ourense, Campus As Lagoas, \\ 32004 Ourense, Spain \\ ${ }^{2}$ CGUL, IDL, Faculdade de Ciências, Universidade de Lisboa, 1700 Lisboa, Portugal \\ ${ }^{3}$ Departamento de Engenharias, Universidade Lusófona, 1749 Lisboa, Portugal \\ ${ }^{4}$ Instituto de Meteorologia, 1749 Lisboa, Portugal
}

\begin{abstract}
Changes in surface air temperature extremes over mainland Portugal since the early 1940s were investigated on the basis of daily maximum and minimum temperatures available from time series from 23 weather stations. The maximum (minimum) temperature decreased by $0.17^{\circ} \mathrm{C}$ decade $^{-1}\left(0.19^{\circ} \mathrm{C}\right.$ decade $\left.^{-1}\right)$ for $1941-1975$ followed by an increase of $0.49^{\circ} \mathrm{C}_{\operatorname{decade}^{-1}}\left(0.54^{\circ} \mathrm{C}\right.$ decade $^{-1}$ ) for 1976-2006, significantly higher than similar trends computed at the global and European scales. A large set of climatic indices was analysed to detect the presence of trends and quantify the variations of different indices for different periods. In the 1976-2006 period, many stations revealed statistically significant positive trends in the annual number of tropical nights, summer days, warm spells, warm nights and warm days. At the seasonal level, we detected statistically significant increments of extreme heat events for spring and summer, and a decrease of cold extremes in winter. We then used the HadRM3 output to study changes in the maximum and minimum temperature distributions and associated changes in the likelihood of extreme events in the future (2071-2100) under 2 change scenarios. Changes obtained for the future are consistent with those found since the mid1970 s in Portugal with an increase in maximum temperature of $3.2^{\circ} \mathrm{C}\left(4.7^{\circ} \mathrm{C}\right.$ ) for the B2 (A2) scenario in summer and $\sim 3.4^{\circ} \mathrm{C}$ in both scenarios for spring. For minimum temperature, the results were similar, with increases for summer (spring) ranging from $2.7^{\circ} \mathrm{C}\left(2.5^{\circ} \mathrm{C}\right)$ in the $\mathrm{B} 2$ scenario to $4.1^{\circ} \mathrm{C}\left(2.9^{\circ} \mathrm{C}\right)$ in the A2 scenario.
\end{abstract}

KEY WORDS: Extremes $\cdot$ Temperature $\cdot$ Portugal $\cdot$ Climate change $\cdot$ Regional Climate Model $\cdot$ RCM

\section{INTRODUCTION}

Global mean surface temperature rose by approximately $0.74^{\circ} \mathrm{C}$ during the century $1906-2005$ (IPCC 2007). Two periods of relative warming were identified, between 1910 and 1945 and also since the 1970s (Jones et al. 1999, Karl et al. 2000). The observed rise in global and regional mean temperatures during the last century (particularly in the last 50 yr) has fueled widespread interest on studies on climate change. Moreover, according to the IPCC Fourth Assessment Report, the average Northern Hemisphere temperatures during the second half of the 20th century were very likely higher than during any other $50 \mathrm{yr}$ period in the last
$500 \mathrm{yr}$ and likely the highest in at least the past $1300 \mathrm{yr}$ (IPCC 2007). In Europe, the last few decades correspond to the period characterised by the steepest temperature increase since the beginning of the 20th century, which is, in general, in agreement with the trends found for the same periods at a global scale (Klein Tank et al. 2002).

For decades, long-term global climate change analysis was based on the analyses on changes in mean values (annual, seasonal and monthly) from observational temperature data sets (Alexander et al. 2006). However, this has changed significantly in the last decade, as several climate change studies have focused on the use of indices in order to assess modifi- 
cations not only in the frequency but also in the intensity of extreme events (e.g. Frich et al. 2002, Klein Tank \& Können 2003, Alexander et al. 2006, Moberg et al. 2006, Santos \& Corte-Real 2006). These indices have been defined following the organisation of a number of dedicated international workshops (Nicholls \& Murray 1999, Manton et al. 2001, Peterson et al. 2001). Usually, extreme events are defined by values of meteorological variables, above or below certain thresholds, linked to low probability occurrence but with major impacts on society and ecosystems (Karl et al. 1997, Heino et al. 1999, Munich Re 2004). However, this leads to the use of a large number of similar but distinct thresholds and associated extreme event definitions by different impact communities. The Expert Team on Climate Change Detection and Indices (ETCCDI) is a joint panel co-sponsored by the World Meteorological Organization (WMO) Commission for Climatology $(\mathrm{CCl})$, the Climate Variability and Predictability project (CLIVAR), and the Joint Commission for Oceanography and Marine Meteorology (JCOMM). It is coordinating an international effort in order to enable global analysis of extreme events by developing a suite of consistent climate change indices and applications, which focus on extreme events related to temperature and precipitation (Klein Tank et al. 2009, Nicholls \& Murray 1999, Peterson et al. 2001).

On a more regional basis, the European Climate Assessment (ECA) project has provided evidence of changes in the frequencies of occurrence of temperature extremes during the second half of the 20th century (Frich et al. 2002, Klein Tank et al. 2002). More recently, the occurrence of summer heat waves over western Europe since 1880 and their relationship with large-scale forcing have been evaluated (Della-Marta et al. 2007). For the Iberian Peninsula, the picture differs considerably between Spain and Portugal. A recent evaluation for Spain used recently digitized long-term time series from 22 stations, showing that there is a larger increase in maximum temperature than minimum temperature since 1973, with a reduction in cold extremes and an increase in warm extremes (Brunet et al. 2007). However, such an assessment has not been attempted for all available long-term stations in Portugal, especially for extreme events; therefore, this constitutes an important objective of the present study. Despite this, recent interdisciplinary studies have shown that there is a steep increase in minimum temperatures, and a smaller but important rise in maximum temperatures, in Portugal (Santos et al. 2002, Santo \& Miranda 2006). However, these studies do not provide the corresponding changes in extreme events related to trends in minimum and maximum temperature throughout the coun- try, as they rely on only 3 stations to assess trends in temperature-related extremes. At a more local scale, however, Santos \& Leite (2009) analysed the long-term variability of Lisbon temperature time series.

Extreme events related to heating or cooling have significant effects on health, natural hazards and socioeconomic activities in Europe, such as the exceptional summer 2003 heat wave (INVS 2003, Beniston 2004, Burt 2004, Schär et al. 2004, Trigo et al. 2005, Díaz et al. 2006), including Portugal, where the heat wave induced the largest value $(450,000 \mathrm{ha})$ of summer burned area ever (Trigo et al. 2006) and $>2300$ excess deaths (Trigo et al. 2009). Therefore, this event is particularly relevant for evaluating the evolution of extreme events in the past century, but also for computing the likelihood of their future occurrence under different climate change scenarios. For this purpose, regional climate models (RCMs) constitute an important tool for providing information not only on average conditions, but also on future projections of extreme events in certain regions. The reliability of these projections is increasing, owing to advances in modelling and understanding of the physical processes of the climate system. For the European region, annual mean temperatures are likely to increase more than the global mean. Seasonally, the largest warming is likely to be in northern Europe in winter and in the Mediterranean area in summer (IPCC 2007). Moreover, changes in frequencies of occurrence of temperature extremes that are most likely to affect Europe in future scenarios were also analysed in several studies (Clark et al. 2006, Tebaldi et al. 2006, Beniston et al. 2007).

The main aims of the study are twofold. (1) To analyse the evolution (trends and variability) of daily maximum, minimum and mean temperature, as well as frequencies of occurrence of temperature extremes over Portugal since 1940. In order to do so, we computed several temperature indices widely studied on a global basis (Frich et al. 2002, Klein Tank \& Können 2003, Alexander et al. 2006). (2) To compute changes of the maximum and minimum temperature distributions, and associated changes in the likelihood of occurrence of extreme events in the future under different climate change scenarios. For future scenarios, our analysis will be based on the output of an RCM.

\section{DATA AND METHODOLOGY}

\subsection{Analysis period and data selection}

\subsubsection{Station data}

The daily maximum and minimum temperature data set used in the present study comprises the period of 
Table 1. Characteristics of the climatological weather stations used in the present study. Lat.: latitude; Long.: Longitude; Alt.: Altitude

\begin{tabular}{|llcccc|}
\hline & Station & $\begin{array}{c}\text { Lat. } \\
\left({ }^{\circ} \mathrm{N}\right)\end{array}$ & $\begin{array}{c}\text { Long. } \\
\left({ }^{\circ} \mathrm{W}\right)\end{array}$ & $\begin{array}{c}\text { Alt. } \\
(\mathrm{m})\end{array}$ & Period \\
\hline 1 & Montalegre & 41.82 & 07.78 & 1005 & $1941-2006$ \\
2 & Bragança & 41.80 & 06.73 & 690 & $1941-2006$ \\
3 & Braga & 41.55 & 08.40 & 190 & $1941-2006$ \\
4 & Régua & 41.17 & 07.80 & 65 & $1941-2006$ \\
5 & Pinhão & 41.17 & 07.55 & 130 & $1941-2006$ \\
6 & Porto/Serra Pilar & 41.13 & 08.60 & 93 & $1941-2006$ \\
7 & Penhas Douradas & 40.42 & 07.55 & 1380 & $1941-2006$ \\
8 & Coimbra/Bencanta & 40.15 & 08.47 & 141 & $1941-2006$ \\
9 & Alvega & 39.47 & 08.05 & 51 & $1949-2006$ \\
10 & Cabo Carvoeiro & 39.35 & 09.40 & 32 & $1941-2006$ \\
11 & Portalegre & 39.28 & 07.42 & 597 & $1942-2006$ \\
12 & Elvas & 38.88 & 07.15 & 208 & $1941-2006$ \\
13 & Cabo Roca & 38.78 & 09.50 & 142 & $1941-2006$ \\
14 & Lisboa/Geofísico & 38.72 & 09.15 & 77 & $1941-2006$ \\
15 & Pegões & 38.60 & 08.60 & 64 & $1941-2006$ \\
16 & Évora & 38.53 & 07.88 & 200 & $1941-2006$ \\
17 & Setúbal & 38.52 & 08.90 & 35 & $1949-2006$ \\
18 & Amareleja & 38.22 & 07.22 & 192 & $1963-2006$ \\
19 & Beja & 38.02 & 07.87 & 246 & $1957-2006$ \\
20 & Alvalade & 37.95 & 08.40 & 61 & $1941-2003$ \\
21 & V. R. S. António & 37.20 & 07.40 & 7 & $1949-2006$ \\
22 & Sagres & 37.02 & 08.95 & 40 & $1952-2006$ \\
23 & Faro & 37.02 & 07.98 & 8 & $1966-2006$ \\
\hline
\end{tabular}

analysis between 1941 and 2006. Data from 23 climatological weather stations (Table 1, Fig. 1) were chosen because of their appropriate spatial distribution, and taking into account data quality. Despite the relative good spatial distribution of the stations, it is also important to note that most of the climatological weather stations are located below $500 \mathrm{~m}$ (Table 1), with only 4 stations being situated above this altitude (Montalegre, Bragança, Penhas Douradas and Portalegre).

Climatic time series typically exhibit spurious (nonclimatic) jumps and/or gradual shifts owing to changes in station location, instrumentation, environment or observation practices (Aguilar et al. 2003). In daily resolution climatic time series, there are also some missing observation days. Because the degree of homogeneity and completeness of a daily resolution series strongly determines the type of analysis of extremes that can be undertaken (see e.g. Moberg et al. 2000, Tuomenvirta 2000), data quality control is a key aspect.

Climate observational data presented in this study were supplied by the Instituto de Meteorologia de Portugal (IM) and we have only considered stations where missing values comprised less than $5 \%$ of all values. All time series were checked in advance by the IM quality control procedures. The procedure aims to identify errors in data processing, such as errors in manual input data such as daily maximum temperature less than daily minimum temperature, nonexistent

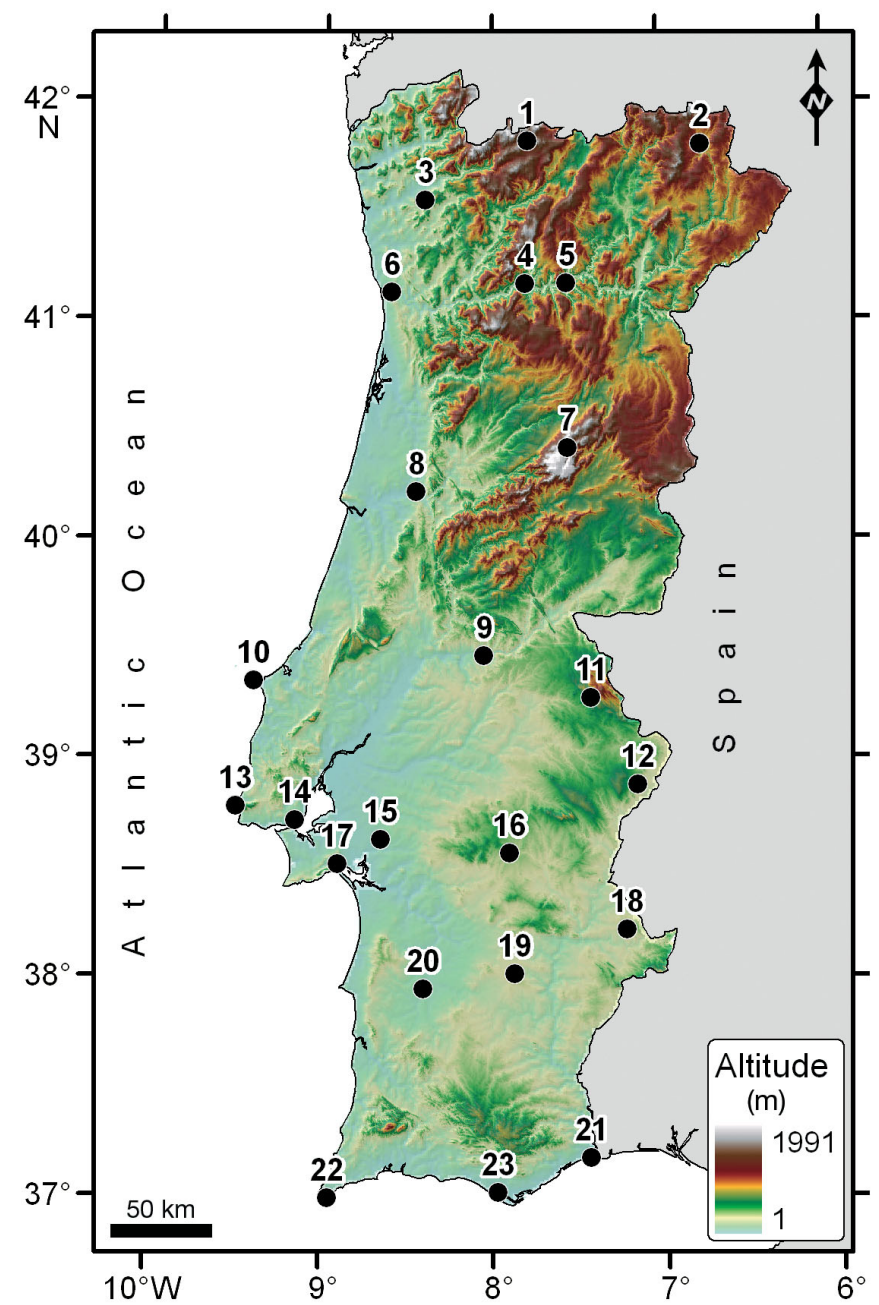

Fig. 1. Locations of the climatological weather stations used in the present study. The topography of continental Portugal is also shown. Stations are identified in Table 1

dates and erroneous outliers. Although the series have undergone routine quality control procedures, another quality step was assured using the procedure in RClimDex, where the main purpose is to identify errors in data (http://cccma.seos.uvic.ca/ETCCDMI/software. shtml). Outliers in daily maximum, minimum and mean temperatures are identified if they fall outside a given pre-defined range. In this case, the range is defined as lying within 3 standard deviations (SD) of the climatological mean of the value for the day. Daily maximum and minimum temperature values outside this range were manually checked and edited on a case-by-case basis when needed.

Most of the data used in the present study were already used in important studies of climate change in Portugal (Santos et al. 2002, Santos \& Miranda 2006). In these studies, 3 absolute homogeneity tests were applied: the often-used standard normal homogeneity test, for a single break point (Alexandersson 1986, 
Alexandersson \& Moberg 1997); the range test (Buishand 1982); and the classical von Neumann ratio (von Neumann 1941). Several stations (including Lisbon) revealed significant jumps in the transition of the mean temperature between 1940 and 1941. These changes are related to the creation of the National Meteorological Service (SNM) in 1941; several new meteorological stations were implemented and similar specifications were adopted by older and newer stations throughout the country. This is one of the main reasons for us to restrict our entire analysis from 1941 onwards (even for stations with longer available time series). Additionally, the time period for several stations (e.g. Alvega, Beja, Setúbal and Amareleja) was selected to prevent inhomogeneities in the series, using metadata to determine the dates of changes in weather station location.

Consequently, in the present study we chose to analyse 23 weather stations for a specific time period, which balanced missing values and good spatial coverage, and reduced the probability of inhomogeneities in the time series.

In order to more thoroughly assess the possible inhomogeneities, we applied a homogeneity test using reference time series. We used the RHtestsV3 software package (http://cccma.seos.uvic.ca/ETCCDMI/ software.shtml), which allowed us to detect multiple change-points (shifts) that could affect data series. It is based on the penalised maximal $t$-test (Wang et al. 2007) and the penalised maximal $F$-test (Wang 2008b), which are embedded in a recursive testing algorithm (Wang 2008a). The test was separately applied to monthly maximum and minimum temperatures $\left(T_{\max }\right.$ and $T_{\min }$, respectively) using the Lisbon time series as the reference series. Results show that a few time series present non-negligible change-points.

Unfortunately, the available metadata for the 23 time series used in the present study are limited to the change in the location of the weather station. It is important to emphasise that virtually all changes in location occurred prior to 1941 and not afterwards, and it is therefore not possible to attribute the most probable reason for the inhomogeneities observed in the data. After weighing the pros and cons, we decided not to correct the inhomogeneities in the few time series that could have improved from such a procedure, because it is a very challenging issue and must be done with extreme caution.

\subsubsection{RCM data}

Climate change simulation scenarios were obtained from the PRUDENCE project (http://prudence.dmi.dk). The project provides European high-resolution data
$(50 \mathrm{~km})$ for both the recent-past climate (control period 1961-1990) and the future climate at the end of the 21st century (scenario period 2071-2100) using different RCMs (Jacob et al. 2007). These RCMs were forced by a global atmospheric climate model, the HadAM3H (Pope et al. 2000). Additional information on the characteristics of the PRUDENCE experiments can be found on their website and in Christensen \& Christensen (2007). In general, the different model simulations in the PRUDENCE project present lower bias in the winter months than in the summer months when one compares the recent-past climate, especially for the Iberian Peninsula (Jacob et al. 2007). Here we chose to use the data from the Hadley Centre RCM (HadRM3) simulations. The HadRM3 presents low temperature bias in winter months whereas in summer months this bias is higher (Jacob et al. 2007). This higher bias in summer months follows the tendency of the driving global climate model (HadAM3H) used in the PRUDENCE project (Moberg \& Jones 2004). Despite this apparent bias of the HadRM3 for the Iberian Peninsula, we chose this model because previous climate changes studies in Portugal not only used an old version of the HadRM model (Santos et al. 2002), but also used different simulation runs with the HadRM3 (Santos \& Miranda 2006) and, therefore, an easier and more complete comparison can be made with the previous studies for Portugal.

We have used the HadRM3 maximum and minimum temperatures relative to the IPCC emissions scenarios A2 and B2. When comparing both scenarios one can observe that the A2 scenario bears a higher concentration of $\mathrm{CO}_{2}$, a larger human population, higher energy consumption, scarcer resources and less diverse technology (Nakicenovic \& Swart 2000).

\subsection{Indices}

A total of 17 temperature (maximum and minimum)related indices were computed (Table 2). All of these indices are recommended by the ETCCDI, and were used in several previous studies about changes in climate extremes (Alexander et al. 2006, Frich et al. 2002, Klein Tank et al. 2002). A brief description of the indices is presented in Table 2 and the extended definition of the indices is available at the ETCCDI website (http://cccma.seos.uvic.ca/ETCCDMI/). These indices were chosen in order to assess the changes in global climate, particularly changes in intensity, frequency and duration of temperature extremes. Based on Alexander et al. (2006), the indices were divided into 4 categories:

(1) Percentile-based indices, which include the occurrence of warm nights (TN90), warm days (TX90), 
Table 2. Definitions of selected indices used for analysis of extreme temperature in Portugal. The present study focused on those indices that are underlined. $T_{\max }$ : maximum temperature; $T_{\min }$ : minimum temperature

\begin{tabular}{|c|c|c|}
\hline Index & Definition & Unit \\
\hline \multicolumn{3}{|c|}{ Percentile-based } \\
\hline TX90 & $\begin{array}{l}\text { Number of days with } T_{\max }>90 \text { th percentile } \\
\text { reference period of daily } T_{\max }\end{array}$ & d \\
\hline$\underline{\text { TX10 }}$ & $\begin{array}{l}\text { Number of days with } T_{\max }<10 \text { th percentile } \\
\text { reference period of daily } T_{\max }\end{array}$ & d \\
\hline$\underline{\text { TN90 }}$ & $\begin{array}{l}\text { Number of days with } T_{\min }>90 \text { th percentile } \\
\text { reference period of daily } T_{\min }\end{array}$ & $\mathrm{d}$ \\
\hline$\underline{\text { TN10 }}$ & $\begin{array}{l}\text { Number of days with } T_{\min }<10 \text { th percentile } \\
\text { reference period of daily } T_{\min }\end{array}$ & $\mathrm{d}$ \\
\hline \multicolumn{3}{|c|}{ Absolute } \\
\hline TXx & Maximum value of daily $T_{\max }$ & ${ }^{\circ} \mathrm{C}$ \\
\hline TXn & Minimum value of daily $T_{\max }$ & ${ }^{\circ} \mathrm{C}$ \\
\hline TNx & Maximum value of daily $T_{\min }$ & ${ }^{\circ} \mathrm{C}$ \\
\hline TNn & Minimum value of daily $T_{\min }$ & ${ }^{\circ} \mathrm{C}$ \\
\hline \multicolumn{3}{|c|}{ Threshold } \\
\hline$\underline{\mathrm{FD}}$ & $\begin{array}{l}\text { Frost days; number of days with daily } \\
T_{\min }<0^{\circ} \mathrm{C}\end{array}$ & d \\
\hline$\underline{\mathrm{ID}}$ & $\begin{array}{l}\text { Ice days; number of days with daily } \\
T_{\max }<0^{\circ} \mathrm{C}\end{array}$ & $\mathrm{d}$ \\
\hline$\underline{\mathrm{SU}}$ & $\begin{array}{l}\text { Summer days; number of days with } \\
\text { daily } T_{\max }>25^{\circ} \mathrm{C}\end{array}$ & d \\
\hline$\underline{\mathrm{TR}}$ & $\begin{array}{l}\text { Tropical nights; number of nights with } \\
\text { daily } T_{\min }>20^{\circ} \mathrm{C}\end{array}$ & d \\
\hline \multicolumn{3}{|c|}{ Duration } \\
\hline$\underline{\text { WSDI }}$ & $\begin{array}{l}\text { Warm spell duration index; annual count } \\
\text { of days with at least } 6 \text { consecutive days } \\
\text { when } T_{\max }>90 \text { th percentile reference } \\
\text { period }\end{array}$ & $\mathrm{d}$ \\
\hline$\underline{\mathrm{CSDI}}$ & $\begin{array}{l}\text { Cold spell duration index; annual count } \\
\text { of days with at least } 6 \text { consecutive days } \\
\text { when } T_{\min }<10 \text { th percentile reference } \\
\text { period }\end{array}$ & d \\
\hline$\underline{\text { GSL }}$ & Growing season length & d \\
\hline \multicolumn{3}{|l|}{ Other } \\
\hline$\underline{\text { DTR }}$ & $\begin{array}{l}\text { Diurnal temperature range; yearly mean } \\
\text { difference between } T_{\max } \text { and } T_{\min }\end{array}$ & ${ }^{\circ} \mathrm{C}$ \\
\hline ETR & $\begin{array}{l}\text { Extreme temperature range; difference } \\
\text { between TXx and TNn }\end{array}$ & ${ }^{\circ} \mathrm{C}$ \\
\hline
\end{tabular}

cold nights (TN10) and cold days (TX10), allowing us to evaluate the extent to which extremes are changing.

(2) Absolute indices, which represent maximum or minimum values within a year. In this case, we studied the maximum daily minimum temperature (TNx), the maximum daily maximum temperature ( $\mathrm{TXx})$, the minimum daily minimum temperature (TNn) and the minimum daily maximum temperature (TXn).

(3) Threshold indices, which are defined as the number of days in which a maximum or minimum temperature falls above or below a fixed threshold. The annual occurrence of frost days, ice days, summer days and tropical nights was analysed.

(4) Duration indices, which define periods of excessive warmth (warm spell duration index, WSDI) and cold (cold spell duration index, CSDI). The growing season length (GSL) was also computed.

(5) Other indices, which do not fit into any categories above, include diurnal temperature range (DTR) and extreme temperature range (ETR).

All indices were computed on an annual basis but, for percentile-based indices, seasonal values were also computed and analysed. The reference period considered is the climatological normal period 1961-1990. After considering the relevance of all results, we opted to restrict the analysis to the indices underlined in Table 2.

\subsection{Methods}

We decided not to grid the station data (e.g. Alexander et al. 2006) but to adopt the approach used by Klein Tank \& Können (2003), who considered each individual station independently. We adopted this because these stations provide an appropriate coverage (stations cover approximately the entire country) and good representativeness for human impact assessment studies (the large majority of inhabitants of Portugal live within $15 \mathrm{~km}$ of each meteorological station).

After quality control (see section 2.1 for details), we computed the average maximum, minimum and mean temperature time series (Fig. 2) based on the 23 meteorological stations (Table 1, Fig. 1) and plotted the respective trend. The indices mentioned in Section 2.2 (Table 2) were computed using the RClimDex software.

In order to evaluate trends, we made use of the method developed by Tomé \& Miranda (2004) that allows us to determine linear trends over 2 consecutive sub-periods that satisfy the constraint of continuity between trends. Moreover, this approach also enables us to detect where the change-point in temperature trends occur. We initially analysed annual temperature trends using this approach, i.e. not determining the change-point in the trend but allowing it to be detected objectively by the program. For all stations, this change-point occurred around the mid-1970s. Due to the fact that this value is very close to that found by Karl et al. (2000) at a global scale, we chose to impose fixed breaks to estimate the trends. Consequently, we used the standard breakpoints obtained by Karl et al. (2000)-1945 and 1975 - thus leading to the two 31-yr sub-periods 1945-1975 and 1976-2006. For Faro and Amareleja, trends in the first sub-period (1945-1975) were not considered due to the fact that the initial data were only collected after 1962. Additionally, we used the Mann-Kendall test to evaluate the level of statistical significance associated with every linear trend computed $(\alpha=0.05)$. 


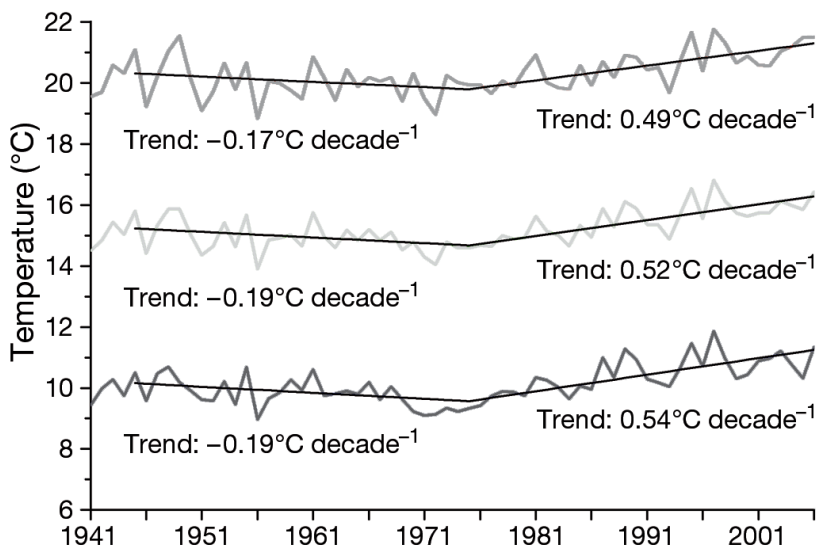

Fig. 2. Interannual variability of maximum (mid-grey), minimum (dark grey) and mean (light grey) temperature. The times series displayed correspond to the average of the 23 meteorological stations. Respective trends for the 2 subperiods are also shown (black lines)

As mentioned earlier, we used daily maximum and minimum temperature simulated with the HadRM3 on a $50 \times 50 \mathrm{~km}$ resolution (which corresponds approximately to a $0.44^{\circ} \times 0.44^{\circ}$ latitude $\times$ longitude grid). The ability of the model to reproduce the present climate in the study area was also assessed. For the latter, we compared the seasonal percentile distribution (on a $1 \%$ step) simulated with the model against the climatological observations for both variables and relative to the control period (1961-1990). These results help to determine the level of confidence of the HadRM3 model for the region of study.

Finally, for future scenarios, we provide a comparison of the seasonal probability distributions for $T_{\max }$ and $T_{\min }$ simulated with the model for the control period (1961-1990) against the A2 and B2 simulations for the 2071-2100 period.

\section{TRENDS IN TEMPERATURE AND EXTREME INDICES}

\subsection{Temperature in Portugal}

The global mean surface temperature has increased between 1906 and 2005 (IPCC 2007). Furthermore, the increment was not continuous but concentrated on 2 periods of relative warming (between 1910 and 1945 and since the 1970s), with a cooling period in between (Jones et al. 1999, Karl et al. 2000). In order to determine if Portugal has registered the same change, we computed the mean of the 23 different weather stations for $T_{\max }, T_{\min }$ and mean temperature $\left(T_{\text {mean }}\right)$ and plotted the interannual variability (Fig. 2). Results obtained appear to be in line with those representing the global mean temperature, with a decrease in tem- perature between the 1940s until the mid-1970s, followed by a clear increase afterwards. For $T_{\max }\left(T_{\min }\right)$, there is a decrease of $0.17^{\circ} \mathrm{C}$ decade $^{-1}\left(0.19^{\circ} \mathrm{C}\right.$ decade $^{-1}$ ) during the 1941-1975 period ( $\mathrm{p}<0.05$ for $\left.T_{\min }\right)$. For the 1976-2006 period, we observed an increase of $0.49^{\circ} \mathrm{C}$ decade $^{-1}\left(0.54^{\circ} \mathrm{C}\right.$ decade $\left.^{-1}\right)$ (both $\mathrm{p}<0.05)$. It is also important to note that, similar to other regions in the world, the steepest increase was observed for $T_{\min }$, which affects the DTR (Vose et al. 2005).

Since 1976 there has been a $0.52^{\circ} \mathrm{C}$ decade ${ }^{-1}$ increase in the daily trend of $T_{\text {mean }}(\mathrm{p}<0.05)$, a value that is compatible with the $0.42^{\circ} \mathrm{C}$ decade $^{-1}$ between 1976 and 1999 found for Europe by Klein Tank \& Können (2003). However, this value is substantially higher than the global land-only temperature trends (1979-2005) described in the last IPCC assessment, which range from 0.188 to $0.315^{\circ} \mathrm{C}$ decade $^{-1}$, depending on the temperature data set (IPCC 2007). It is also important to note that, for Portugal, 8 of the 10 warmest years occurred in the last $20 \mathrm{yr}$, with 1997 ranking as the warmest year since 1941.

\subsection{Annual indices}

In this section we evaluate trends obtained for the indices described in Table 2 at an annual scale. In order to aggregate the vast amount of values, results are summarized for all temperature indices (Table 3) and a more in-depth analysis is performed for some indices.

Analysing the complete period (1941-2006), the most striking results come from the percentile- and threshold-based indices. During this period, there was a significant increase (decrease) of heat (cold)-related percentile indices for more than half of the considered weather stations. For threshold indices, there was an increment in the number of summer days and tropical nights that was accompanied by a decrease in the number of frost and ice days, although results for the latter are only significant for 3 stations.

Focusing on the 2 separate periods, a different picture emerges, with the first sub-period (1945-1975) dominated by negative (positive) trends for heat (cold)related indices. On the contrary, during the second sub-period (1976-2006) there was a widespread inversion of this pattern, with positive (negative) trends found for the heat (cold)-related indices for the majority of the locations.

We also show an example of the annual series of the occurrence of summer days and tropical nights (Fig. 3) for 3 important stations: Lisbon (the capital and largest city in Portugal), Porto (the second largest city) and Bragança (interior, northern city). The first comment 
Table 3. Number of weather stations with positive $(+)$ and negative (-) annual trends for each index. Corresponding number of significant trends (Sig.) at the $5 \%$ level are also shown. See Table 2 for index definitions

\begin{tabular}{|c|c|c|c|c|c|c|}
\hline \multirow[b]{4}{*}{ TX90 } & \multicolumn{6}{|c|}{$\longrightarrow$ Period } \\
\hline & \multicolumn{2}{|c|}{$1941-2006$} & \multicolumn{2}{|c|}{$1945-1975$} & \multicolumn{2}{|c|}{ 1976-2006 } \\
\hline & + & - & + & - & + & - \\
\hline & & & & & & \\
\hline Total & 20 & 3 & 1 & 20 & 23 & 0 \\
\hline Sig. & 14 & 0 & 0 & 14 & 19 & 0 \\
\hline TX10 & & & & & & \\
\hline Total & 3 & 20 & 18 & 3 & 2 & 21 \\
\hline Sig. & 1 & 11 & 9 & 0 & 1 & 17 \\
\hline TN90 & & & & & & \\
\hline Total & 22 & 1 & 0 & 21 & 23 & 0 \\
\hline Sig. & 16 & 0 & 0 & 13 & 17 & 0 \\
\hline TN10 & & & & & & \\
\hline Total & 3 & 20 & 19 & 2 & 2 & 21 \\
\hline Sig. & 2 & 14 & 11 & 0 & 1 & 19 \\
\hline FD & & & & & & \\
\hline Total & 5 & 18 & 11 & 10 & 6 & 17 \\
\hline Sig. & 1 & 8 & 4 & 0 & 0 & 4 \\
\hline SU & & & & & & \\
\hline Total & 15 & 8 & 3 & 18 & 21 & 2 \\
\hline Sig. & 6 & 1 & 1 & 11 & 15 & 0 \\
\hline ID & & & & & & \\
\hline Total & 0 & 3 & 1 & 2 & 0 & 3 \\
\hline Sig. & 0 & 2 & 1 & 0 & 0 & 1 \\
\hline TR & & & & & & \\
\hline Total & 22 & 1 & 5 & 16 & 23 & 0 \\
\hline Sig. & 13 & 0 & 0 & 5 & 11 & 0 \\
\hline WSDI & & & & & & \\
\hline Total & 17 & 6 & 0 & 21 & 23 & 0 \\
\hline Sig. & 6 & 2 & 0 & 14 & 9 & 0 \\
\hline CSDI & & & & & & \\
\hline Total & 6 & 17 & 5 & 16 & 10 & 13 \\
\hline Sig. & 1 & 9 & 0 & 1 & 1 & 4 \\
\hline GSL & & & & & & \\
\hline Total & 23 & 0 & 14 & 7 & 15 & 8 \\
\hline Sig. & 10 & 0 & 1 & 0 & 1 & 0 \\
\hline DTR & & & & & & \\
\hline Total & 9 & 14 & 6 & 15 & 13 & 10 \\
\hline Sig. & 6 & 10 & 3 & 5 & 7 & 7 \\
\hline
\end{tabular}

worth mentioning is the large difference of occurrence of summer days and tropical nights, with many more summer days than tropical nights throughout the year. On average, Lisbon had a larger number of summer days than Porto (both located on the coastal area of Portugal, differing only in latitude) (Fig. 3). A similar pattern emerges for the 3 stations considered, with a decrease in the number of summer days during the first sub-period followed by an increase for the second sub-period. The same pattern holds for tropical nights (Fig. 3), with a decrease in the number of tropical nights for the first sub-period and an increase in the second sub-period. There has been a substantial and significant increase in tropical nights in Lisbon since 1976. Moreover, for Bragança there are no records of
$>10 \mathrm{~d}$ per year with $T_{\min }>20^{\circ} \mathrm{C}$, and for Porto this has only occurred in 2006.

Indices based on temporal duration are also important as they account for prolonged periods (at least $6 \mathrm{~d}$ in length) subject to extreme temperatures. In Fig. 4, we consider the WSDI, i.e. the annual number of days with $\geq 6$ consecutive days when $T_{\max }$ is higher than the 90th percentile obtained for the reference period. For the period between 1945 and 1975, all weather stations present negative trends for this index, with 14 stations presenting statistically significant trends. By contrast, all stations reveal positive trends for WSDI for the period between 1976 and 2006, with results for 9 stations being statistically significant (all located in the interior region of Portugal). Moreover, a few stations showed an increase of $10 \mathrm{~d}$ decade $^{-1}$. If we take into account the complete period, the majority of weather stations present positive trends.

Table 3 shows the corresponding analysis for the CSDI, i.e. the annual number of days with $\geq 6$ consecutive days when $T_{\min }$ is below the 10th percentile obtained for the reference period. However, the results are not as homogeneous as those of WSDI. The absolute values of CSDI days are quite low (small samples), particularly those relative to the second period, leading to a lack of robustness when assessing the statistical significance of these trends. In any case, this clearly indicates that, in western Iberia, where continental Portugal is located, it is becoming increasingly rare to have $\geq 6$ consecutive days with $T_{\min }$ below the 10th percentile. However, if we perform a similar analysis without the constraining (6 d) factor, results are more robust and homogeneous, as shown in Section 3.3, below. Results for these 2 indices (WSDI and CSDI) are in phase with those attained by Alexander et al. (2006) for Europe, with positive (negative) trends for the WSDI (CSDI), particularly in the last $30 \mathrm{yr}$.

\subsection{Seasonal percentile indices}

In this section we discuss the trend analysis undertaken with percentile indices on a seasonal basis. We have made an effort to focus on these indices because the percentile basis allows easier inter-comparisons between locations. Moreover, they take into account the seasonal cycle of temperature and do not require a minimum number of consecutive days. Results are summarised in Table 4, showing the total number of stations characterised by positive or negative trends, including those that are statistically significant, for each percentile index and for the 3 distinct periods of study considered.

The first set of indices considered are those percentile indices related to heat extremes, namely TX90 
Bragança 120
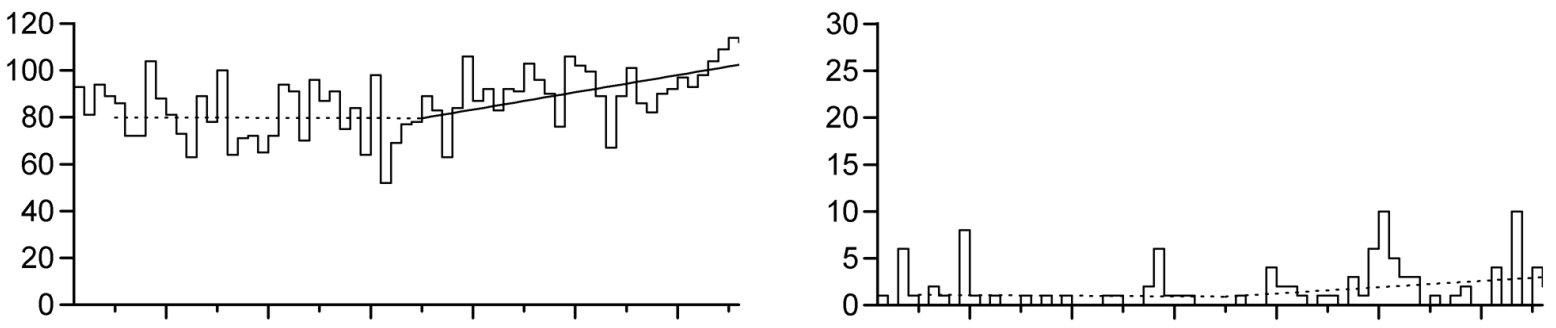

Porto
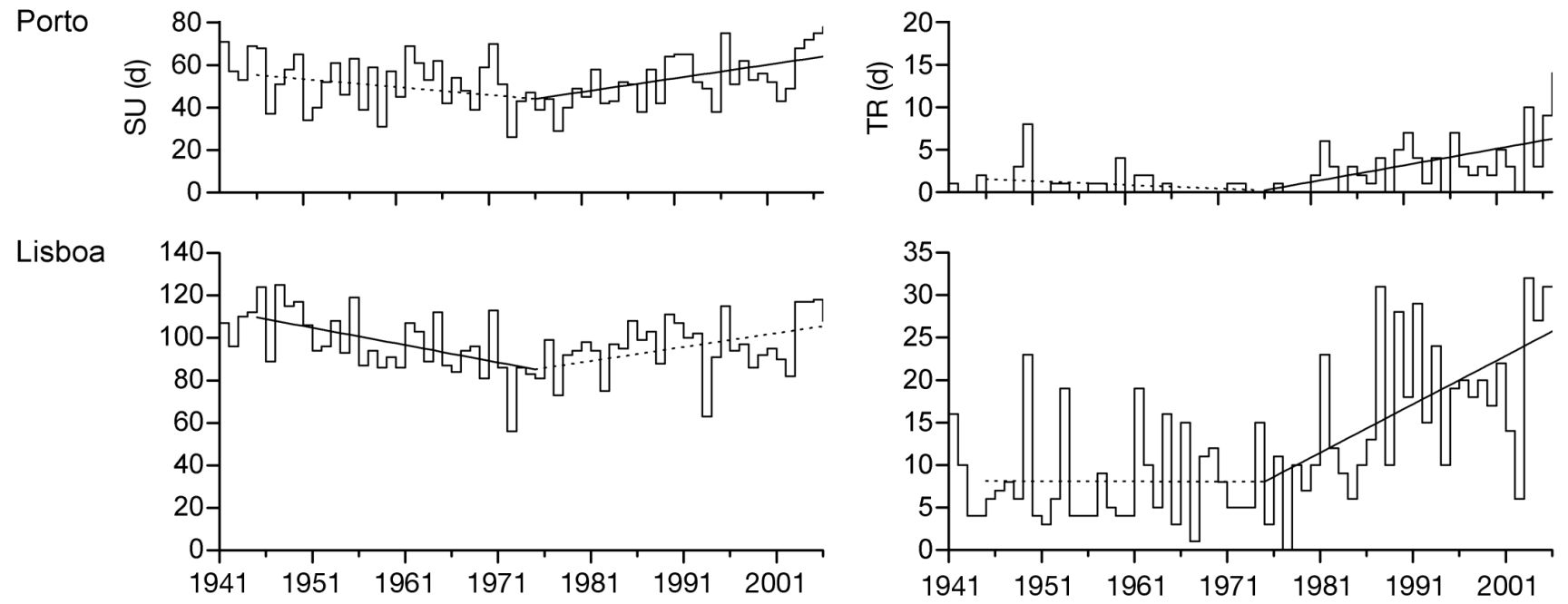

Fig. 3. Interannual variability of (left) summer days, SU, and (right) tropical nights, TR (see Table 2 for definitions), are shown in step plots for Bragança, Porto and Lisboa. Trends for each sub-period (1945-1975 and 1976-2006) are also shown; statistically significant ( $5 \%$ level) trends are indicated by solid lines
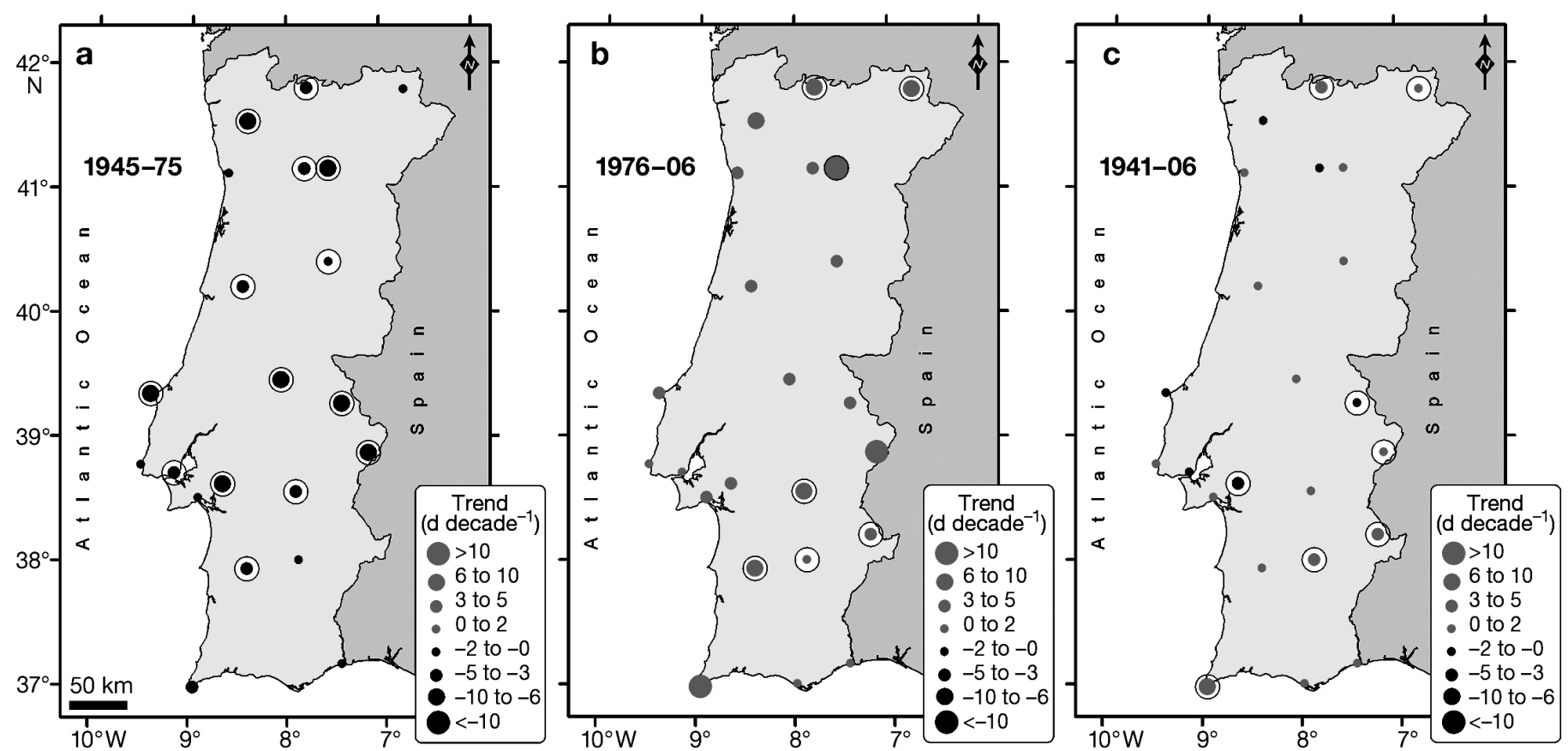

Fig. 4. Decadal trends of the warm spell duration index (WSDI, annual) for the (a) 1945-1975, (b) 1976-2006 and (c) the entire period (1941-2006). Different sizes of the solid circles indicate different magnitudes of the decadal trends. The black circle around the solid circles represents significant trends at the $5 \%$ level 
Table 4. Number of stations with positive (+) and negative (-) seasonal trends for percentile indices. Corresponding number of significant trends (Sig.) at the $5 \%$ level are also shown. See Table 2 for index definitions

\begin{tabular}{|c|c|c|c|c|c|c|c|c|c|c|c|c|}
\hline \multirow[b]{2}{*}{ Season } & \multirow{2}{*}{+} & \multicolumn{3}{|c|}{$-1941-2006$} & \multicolumn{4}{|c|}{$\begin{array}{r}1945-1975 \\
\end{array}$} & \multirow{2}{*}{+} & \multicolumn{2}{|c|}{$1976-2006$} & \multirow[b]{2}{*}{ - Sig. } \\
\hline & & + Sig. & - & - Sig. & + & + Sig. & - & - Sig. & & + Sig. & - & \\
\hline \multicolumn{13}{|l|}{ TX90 } \\
\hline MAM & 22 & 7 & 1 & 0 & 1 & 0 & 20 & 9 & 23 & 19 & 0 & 0 \\
\hline JJA & 23 & 12 & 0 & 0 & 1 & 0 & 20 & 11 & 23 & 19 & 0 & 0 \\
\hline SON & 8 & 1 & 15 & 2 & 6 & 0 & 15 & 5 & 13 & 1 & 10 & 0 \\
\hline DJF & 22 & 10 & 1 & 0 & 5 & 0 & 16 & 5 & 21 & 8 & 2 & 0 \\
\hline \multicolumn{13}{|l|}{ TX10 } \\
\hline MAM & 5 & 0 & 18 & 5 & 21 & 11 & 0 & 0 & 0 & 0 & 23 & 19 \\
\hline JJA & 5 & 0 & 18 & 7 & 19 & 8 & 2 & 1 & 1 & 0 & 22 & 15 \\
\hline SON & 12 & 1 & 11 & 4 & 19 & 12 & 2 & 0 & 3 & 2 & 20 & 2 \\
\hline DJF & 3 & 1 & 20 & 14 & 3 & 0 & 18 & 2 & 4 & 0 & 19 & 5 \\
\hline \multicolumn{13}{|l|}{ TN90 } \\
\hline MAM & 22 & 12 & 1 & 1 & 0 & 0 & 21 & 16 & 23 & 21 & 0 & 0 \\
\hline JJA & 23 & 19 & 0 & 0 & 1 & 0 & 20 & 6 & 23 & 18 & 0 & 0 \\
\hline SON & 19 & 15 & 4 & 0 & 1 & 0 & 20 & 7 & 23 & 13 & 0 & 0 \\
\hline DJF & 21 & 4 & 2 & 0 & 15 & 0 & 6 & 2 & 19 & 0 & 4 & 0 \\
\hline \multicolumn{13}{|l|}{ TN10 } \\
\hline MAM & 5 & 3 & 18 & 5 & 20 & 15 & 1 & 0 & 1 & 0 & 22 & 17 \\
\hline JJA & 1 & 1 & 22 & 13 & 15 & 6 & 6 & 1 & 0 & 0 & 23 & 17 \\
\hline SON & 3 & 2 & 20 & 10 & 20 & 12 & 1 & 0 & 2 & 1 & 21 & 12 \\
\hline DJF & 5 & 2 & 18 & 15 & 8 & 0 & 13 & 2 & 5 & 1 & 18 & 1 \\
\hline
\end{tabular}

and TN90. As a general rule, during the long-term period 1941-2006, there is an increase in the occurrence of TX90 and TN90 days, particularly in summer, but also an important increment during spring and winter. The most significant results are found for summer, with all weather stations presenting positive trends for both indices (12 significant for TX90 and 19 significant for TN90). The evolution of these indices for the first sub-period (1945-1975) is marked by negative trends in TX90 for most stations during all seasons but with more significant trends in the spring and summer. For the TN90 index, one can observe negative trends during the first sub-period for a vast number of stations in spring, summer and autumn (significant for the majority of stations), whereas for winter, positive but non-significant trends were found. For the second subperiod (1976-2006), we depict a generalised significant increase of both TX90 and TN90 days, particularly in spring and summer. For autumn, an increase in TN90 days was also found for all 23 stations, but with significant results only for half of the stations. For winter, 21 (19) stations also presented positive trends for TX90 (TN90), but only 8 were significant for TX90 and none for TN90.

Concerning the cold-related percentile indices, TX10 and TN10, in general the opposite behaviour was found. For the 1941-2006 period, results are dominated by negative trends for all seasons but were particularly significant for winter. For the 1945-1975 period, there was a dichotomy between winter and the remaining seasons, with a relatively widespread increase in TX10 and TN10 days in summer, spring and autumn, and a tendency towards less cool days and nights in winter.
The most significant trends can be observed in summer and autumn. Focusing on the last $30 \mathrm{yr}$ of the analysed period and for all seasons, results are in line with the relatively warmer period described by Karl et al. (2000) and already discussed for Portugal in Section 3.1 (Fig. 2). For Portugal, there was a decrease in TX10 and TN10 days that was statistically significant for the majority of the weather stations for spring and summer.

We derived plots of trends for all indices and seasons; however, for the sake of simplicity we will concentrate on those plots that offer more information, in particular those related to TX90 in spring and TX10 in winter. With the exception of Sagres, all stations presented negative trends during 1945-1975 for TX90 in spring (Fig. 5). By contrast, between 1976 and 2006, all stations presented positive trends for TX90 in spring, with 19 stations presenting statistically significant trends and 9 stations presenting trends larger than $6 \mathrm{~d}$ decade $^{-1}$. When we take into consideration the entire period of analysis, all stations except Cabo Carvoeiro are characterised by positive trends (although only 5 were statistically significant).

The TX10 index trend maps are also shown for the considered periods of analysis (Fig. 6). These trends, in general, are smaller than those found for TX90. There is a decrease in TX10 days for most of the stations, only 2 of which were significant during the first sub-period (1945-1975) and only 5 of which were significant during the second sub-period. If we analyse the entire period of study (1941-2006), the number of TX10 days decreased at 20 stations during the later stages of this period; the trends were statistically significant at 14 of the 20 stations. 


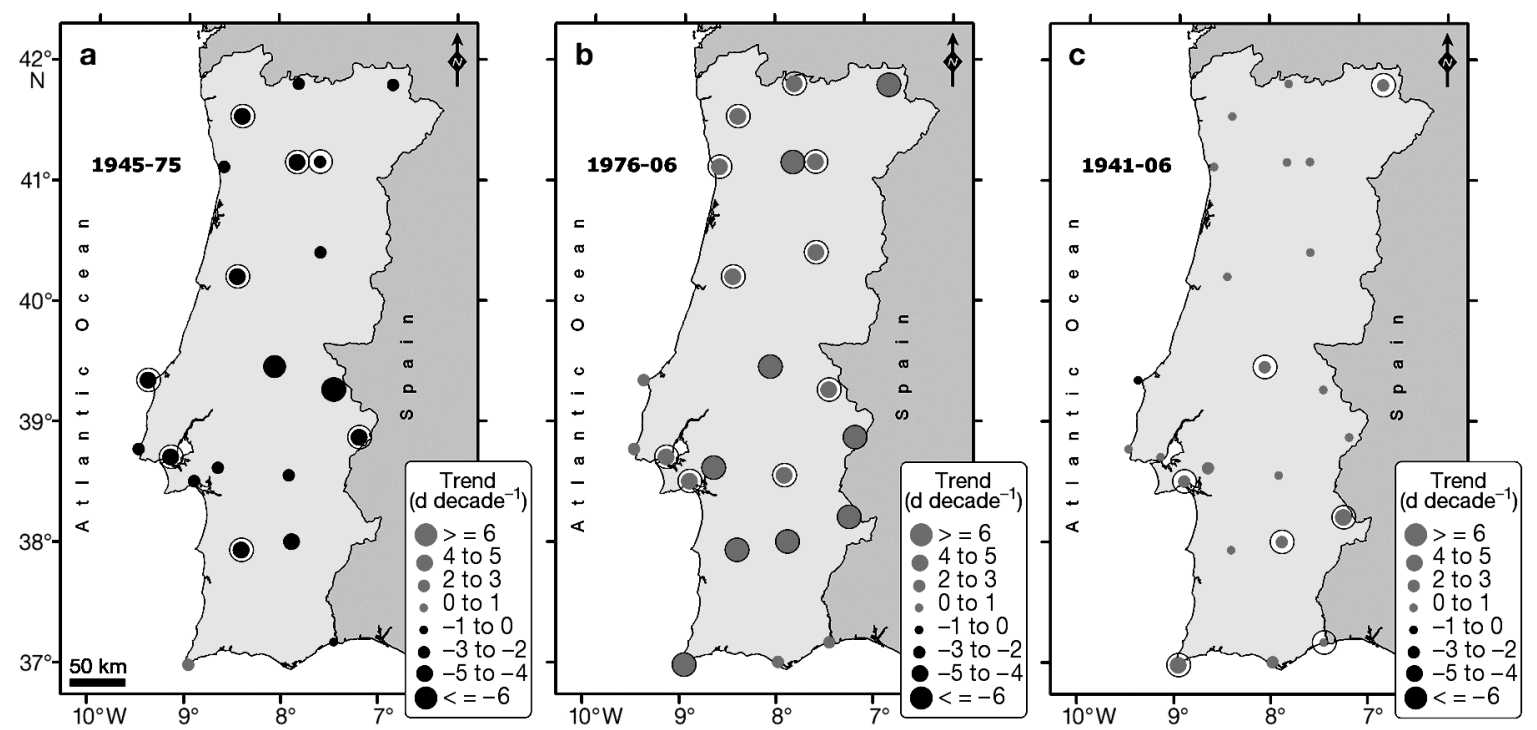

Fig. 5. Decadal trends of the occurrence of warm days (TX90) for spring months for the (a) 1945-1975, (b) 1976-2006 and (c) the entire period (1941-2006). Different sizes of the solid circles indicate different magnitudes of the decadal trends. The black circle around the solid circles represents significant trends at the $5 \%$ level

As indicated earlier, the increase in minimum temperatures in Portugal after 1975 is higher than the corresponding increment in maximum temperature (Fig. 2). For that reason, we also analysed the spatial distribution of the number of TN90 days (hot nights) (Fig. 7). In fact, we detected a generalised (and statistically significant) increment of this index throughout all seasons except winter. For spring and summer, there was an increase of more than $6 \mathrm{~d}$ decade $^{-1}$ since 1976 at more than half of the stations. For winter, the trends were smaller (but again positive for 20 stations) but not significant.

\section{FUTURE SCENARIOS}

The impact of extreme heat wave episodes on human mortality has been established for many urban areas of the world, including Iberian cities (e.g. Dessai 2002, García-Herrera et al. 2005), with impacts in Iberia associated with extreme values of maximum temperature (Dessai 2002, Díaz et al. 2002a,b, GarcíaHerrera et al. 2005, Trigo et al. 2009).

The use of direct output from RCMs can be misleading, particularly if RCMs perform poorly when repro-
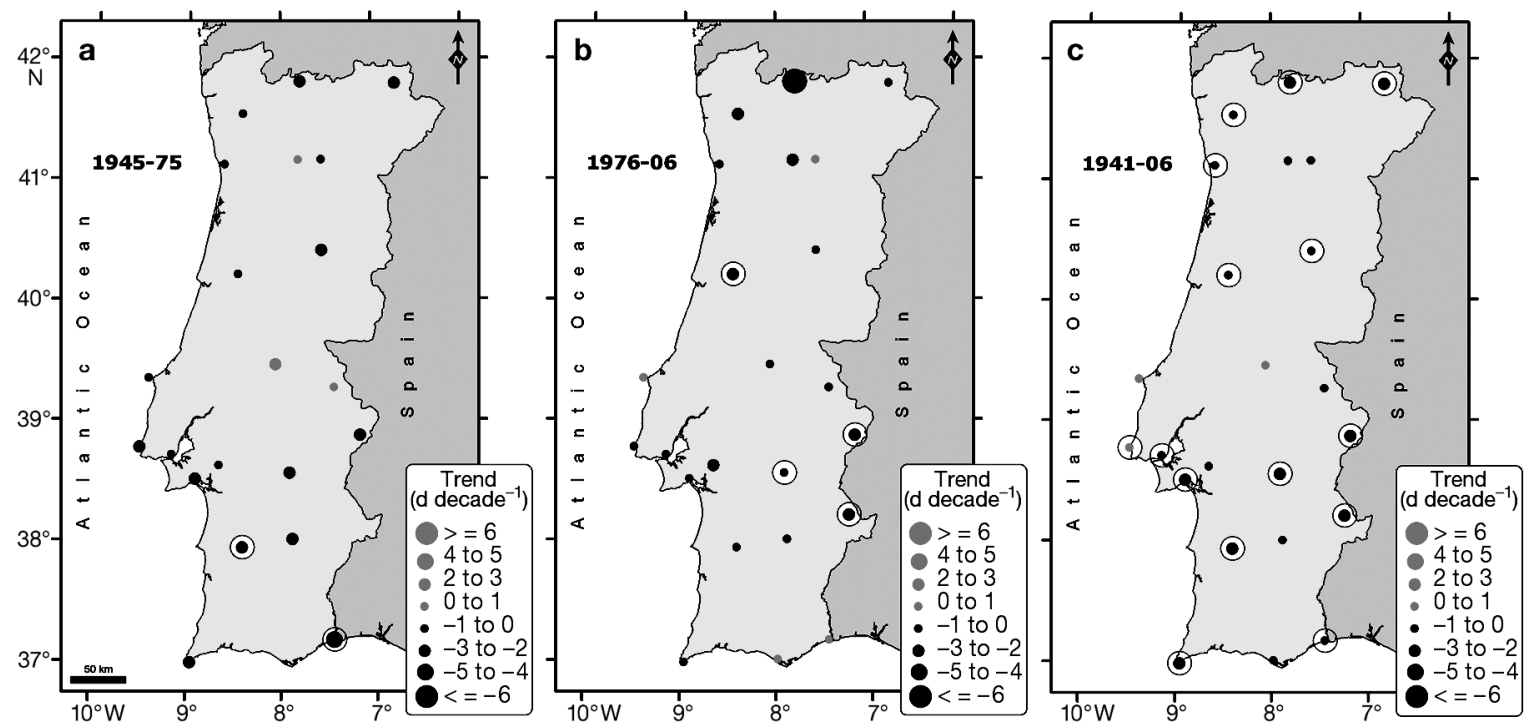

Fig. 6. Decadal trends of the occurrence of cold days (TX10) for winter months for the (a) 1945-1975, (b) 1976-2006 and (c) the entire period (1941-2006). Different sizes of the solid circles indicate different magnitudes of the decadal trends. The black circle around the solid circles represents significant trends at the $5 \%$ level 

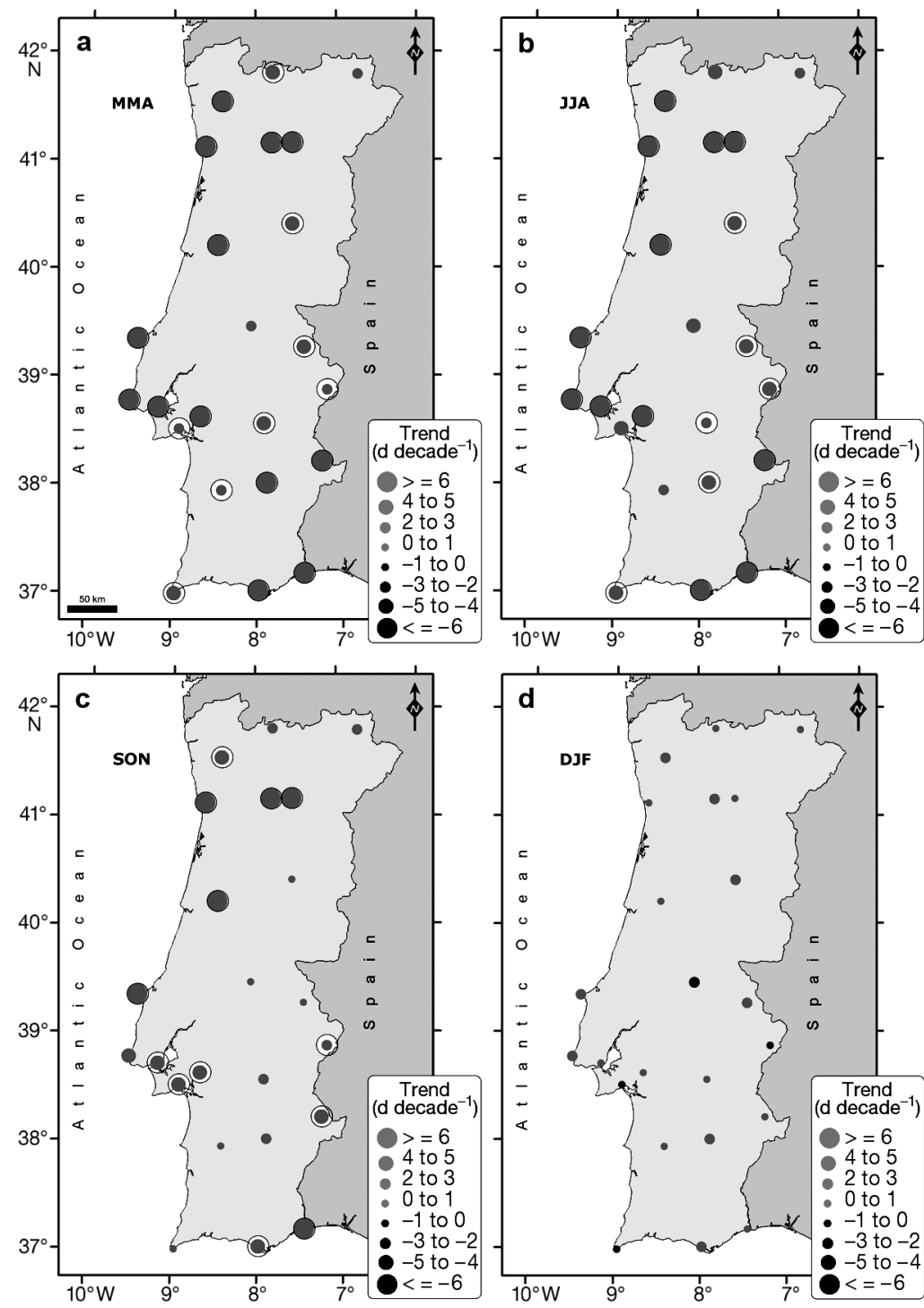

Fig. 7. Decadal trends of the occurrence of warm nights (TN90) for the last sub-period of analysis (1976-2006) and for (a) spring, (b) summer, (c) autumn and (d) winter. Different sizes of solid circles indicate different magnitudes of the decadal trends. The black circle around the solid circles represents significant trends at the $5 \%$ level

ducing the current climate statistics (mean, variance, probability distribution). Thus it is important to test the ability of the model to reproduce the control climate, in this case, the normal period 1961-1990. In order to obtain a daily time series representative of the entire country, we started by constructing a unique time series with all values of $T_{\max }$ and $T_{\min }$ from all 23 climatological weather stations for the control climate period. Afterwards, we computed the seasonal percentiles, in $1 \%$ steps, from 1 to $99 \%$. In addition, we also considered the grid points of the model (for the control climate) that are closest to the 23 climatological weather stations, which were aggregated into a new time series and the corresponding model seasonal percentiles were computed. Finally, we compared the entire set of individual observations (i.e. 23 stations $\times 30 \mathrm{yr}$ $\times 365 \mathrm{~d}=250000$ values) with the corresponding RCM values from the closest grid point (considering each station individually). This approach allows a comparison between the aggregated observed and modelled probability distributions for $T_{\text {max }}$ (Fig. 8a) and $T_{\min }$ (Fig. 8b), by plotting the bias between the control simulation of the HadRM3 for the 1961-1990 period and the climatology for each percentile (from 1 to 99) of the distribution. This approach is not optimal, as the optimal comparison would be achieved by using gridded observations. Because we used a limited number of weather stations (23), the data could not be gridded with sufficient robustness and representativeness; therefore, it was impossible to perform a fair comparison between both data sets. In this way, the results presented in Fig. 8 are an indication of the probable model deficiencies.

In the case of $T_{\max }$ (Fig. 8a), results show a positive bias in all seasons, being especially high in summer (ranging from $1^{\circ} \mathrm{C}$ in the left tail of the distribution and increasing to $4^{\circ} \mathrm{C}$ in the right tail of the distribution) and relatively low in autumn (between 0 and $2{ }^{\circ} \mathrm{C}$ ). Focusing on the winter months, the model's ability to reproduce extreme events (left and right tails of the distribution) can be considered low, whereas the rest of the distribution is well represented by the model. For the spring months, the distribution is relatively better represented for the low values of the distribution (with bias around $0^{\circ} \mathrm{C}$ in some cases) than for the upper values of the distribution, showing that the model is also positively biased. For $T_{\text {min }}$ (Fig. 8b), results show low bias in spring and autumn (between 0 and $1^{\circ} \mathrm{C}$ ), but a stronger positive bias for summer (ranging from 1 to $4^{\circ} \mathrm{C}$ ) is once again present, whereas in winter there seems to be a negative (albeit minor) bias. To summarise, the highest biases are found for $T_{\max }$ and for summer.

Positive summer temperature biases detected for both $T_{\max }$ and $T_{\min }$ were also observed in previous studies using other RCMs. A number of possible factors have been put forward to account for this limitation: circulation biases, parameterization deficiencies or errors in precipitation frequency distribution (Christensen et al. 1997, Noguer et al. 1998, Hageman et al. 


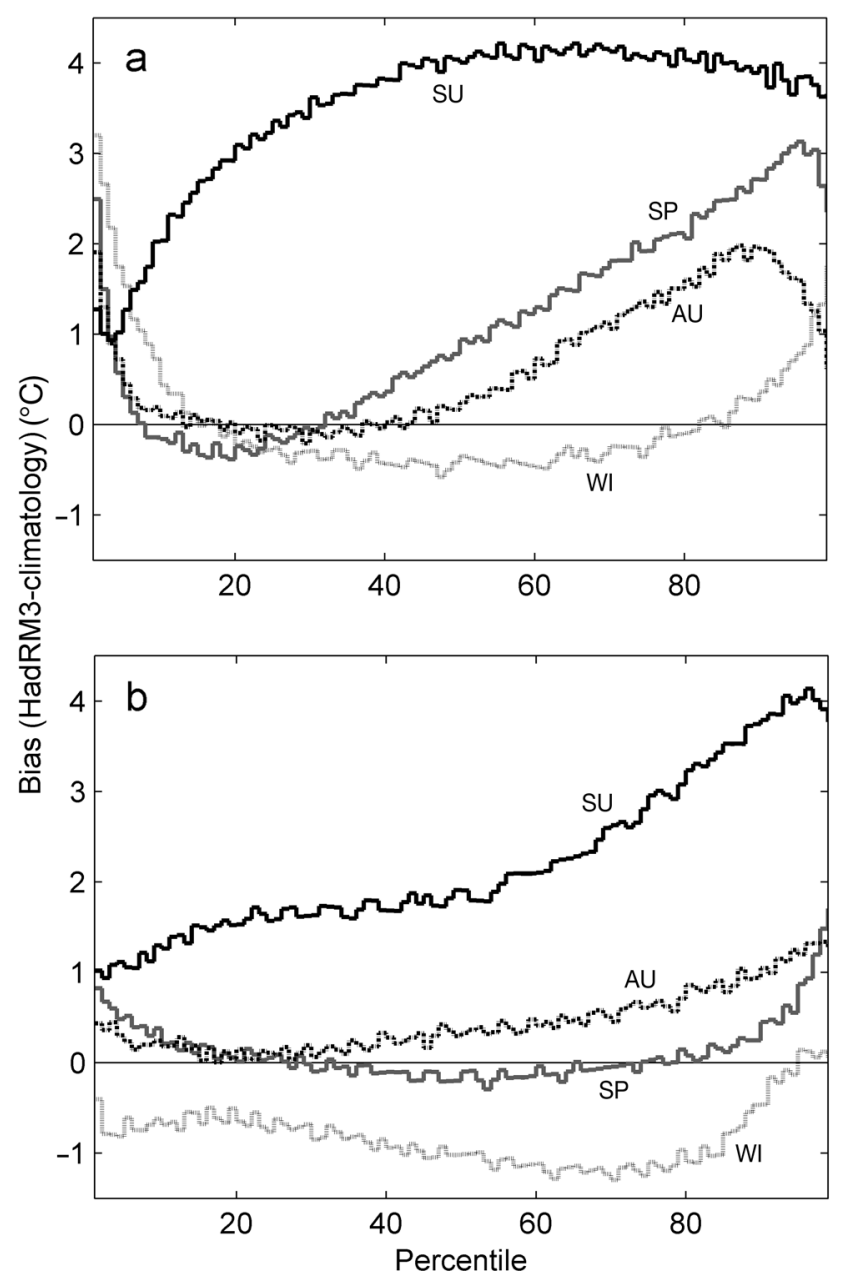

Fig. 8. Bias between the control simulation of HadRM3 for the 1961-1990 period and the climatology for each percentile of the distribution of (a) maximum temperature and (b) minimum temperature for winter (light gray lines), spring (dark gray lines), summer (black lines) and autumn (black dotted lines)

2001). Regarding HadRM3, it has been shown that the main problem with this RCM is associated with the little precipitation observed in summer, implying relatively low values of evaporation and a tendency to dry soils; therefore, the land surface warms too rapidly (Moberg \& Jones 2004). Nevertheless, results obtained in the present study still show a reasonable capacity of the HadRM3 to reproduce the daily distribution of maximum and minimum temperatures for the entire Portuguese territory. It is expected that deficiencies detected in the control run are also applicable to future climate change scenarios, thus offsetting (at least partially) these biases. Despite the bias of the HadRM3 in respect to the observations, especially in summer, Moberg \& Jones (2004) stated that the HadRM3 is a valid model for use in climate change studies, and this model has already been used with success in another climate change study in Portugal (Santos \& Miranda 2006).

As the capacity of the model to reproduce the control climate in the studied area has been tested, the following step is related to the identification of changes for the future climate under 2 IPCC emissions scenarios (B2 and A2) for the end of 21st century (2071-2100). Here the main purpose is to compare the probability distribution for the control climate (1961-1990) simulated with the model and the simulation for the 2 emissions scenarios. The same 23 grid points (closest to the 23 climatological weather stations) employed in the control climate comparison are used. Results are once again presented on a seasonal basis for $T_{\max }$ (Fig. 9a) and $T_{\min }$ (Fig. 9b). In addition, in Table 5, we present the differences $\left({ }^{\circ} \mathrm{C}\right)$ between some selected percentiles $(10,25,50,75$ and 90$)$ in the HadRM3 control simulation (1961-1990 period) and the same percentiles in the B2 and A2 scenarios for $T_{\max }$ and $T_{\min }$.

For $T_{\max }$ (Fig. 9a), there is a projected increase in temperature for all seasons with the highest increases being found for the A2 scenario. For winter, there is an increase of $2.1^{\circ} \mathrm{C}$ in the $T_{\max }$ for the $\mathrm{B} 2$ scenario whereas, in the A2 scenario, this value is slightly higher $\left(2.8^{\circ} \mathrm{C}\right)$. For spring, projected changes are almost equal between the B2 and the A2 scenarios with an increase in $T_{\max }$ of $\sim 3.4^{\circ} \mathrm{C}$. For summer (autumn), these increases range from $3.2^{\circ} \mathrm{C}\left(2.9^{\circ} \mathrm{C}\right)$ in the $\mathrm{B} 2$ scenario to $4.7^{\circ} \mathrm{C}\left(4.4^{\circ} \mathrm{C}\right)$ in the A2 scenario. These increases in the mean values of the distributions also correspond to changes in the distribution percentiles (Table 5). We found asymmetric increases in the different percentiles when comparing the control period and the future scenarios. In general, the highest changes in the percentiles were found for the 75th and

Table 5. Differences $\left({ }^{\circ} \mathrm{C}\right)$ between the selected percentiles $(10,25,50,75$ and 90$)$ in the HadRM3 control simulation (1961-1990 period) and the same percentiles in the B2 and A2 scenarios for maximum and minimum temperature $\left(T_{\max }\right.$ and $T_{\min }$, respectively)

\begin{tabular}{|lcccccccc|}
\hline \multicolumn{4}{c}{ DJF } & \multicolumn{2}{c}{ MAM } & \multicolumn{2}{c}{ JJA } & \multicolumn{2}{c}{ SON } \\
& B2 & A2 & B2 & A2 & B2 & A2 & B2 & A2 \\
\hline$T_{\max }$ & & & & & & & & \\
10 & 2.03 & 2.64 & 1.82 & 2.33 & 2.50 & 3.88 & 2.23 & 3.19 \\
25 & 2.07 & 2.78 & 2.38 & 2.72 & 3.39 & 4.90 & 2.33 & 3.32 \\
50 & 2.04 & 2.71 & 3.16 & 3.46 & 3.52 & 5.00 & 3.05 & 4.48 \\
75 & 2.38 & 2.95 & 4.35 & 4.38 & 3.44 & 4.80 & 3.48 & 5.31 \\
90 & 2.60 & 3.21 & 5.02 & 5.26 & 3.26 & 4.74 & 3.46 & 5.48 \\
$T_{\min }$ & & & & & & & & \\
10 & 2.89 & 3.70 & 1.70 & 2.05 & 2.77 & 4.20 & 2.56 & 3.71 \\
25 & 2.76 & 3.52 & 1.90 & 2.33 & 2.63 & 3.96 & 2.55 & 3.55 \\
50 & 2.45 & 3.26 & 2.45 & 2.79 & 2.54 & 3.97 & 2.76 & 3.72 \\
75 & 2.24 & 3.04 & 2.92 & 3.21 & 2.82 & 4.38 & 2.66 & 3.95 \\
90 & 1.91 & 2.69 & 3.67 & 3.96 & 3.25 & 4.65 & 2.98 & 4.95 \\
\hline
\end{tabular}



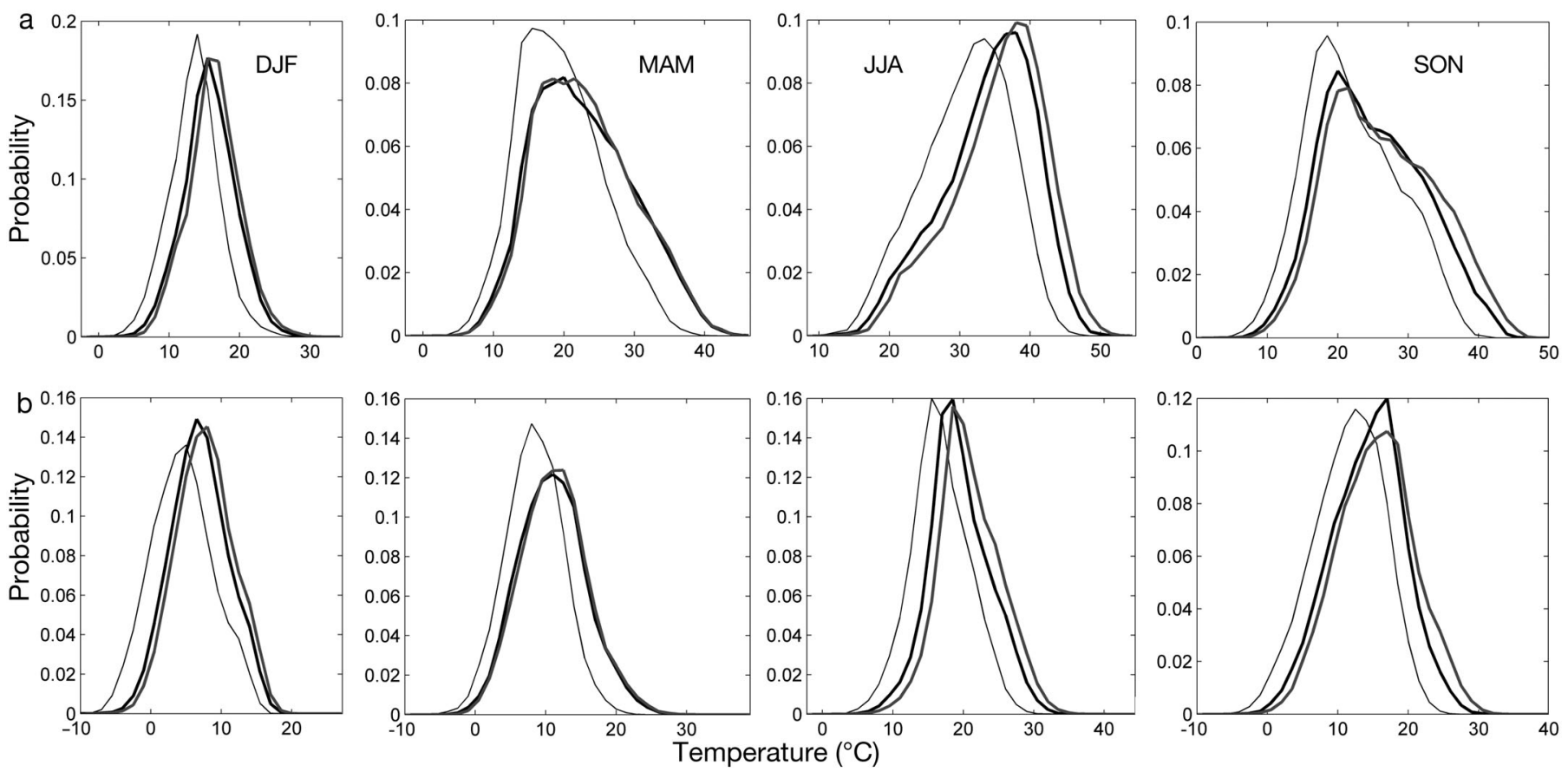

Fig. 9. Changes in the probability distribution for (a) maximum and (b) minimum temperature for the 1961-1990 control period (thin black lines) and the B2 (thick black lines) and A2 scenarios (gray lines)

90th percentiles and the smallest changes were found for the 10th percentile. It is also interesting to note that for spring, changes in the 75th and 90th percentiles (5 and $5.3^{\circ} \mathrm{C}$, respectively) are the highest ones for $T_{\max }$.

Generally speaking, changes foreseen for $T_{\min }$ are similar in magnitude to those projected for $T_{\max }$, with the highest positive changes corresponding to the A2 scenario. For winter, there is an increase of $2.4^{\circ} \mathrm{C}$ for the B2 scenario whereas in the A2 scenario these values increase to $3.2^{\circ} \mathrm{C}$. For summer (spring), these increases range from $2.7^{\circ} \mathrm{C}\left(2.5^{\circ} \mathrm{C}\right)$ in the $\mathrm{B} 2$ scenario to $4.1^{\circ} \mathrm{C}\left(2.9^{\circ} \mathrm{C}\right)$ in the $\mathrm{A} 2$ scenario. It is also interesting to note that for autumn, the model projects an increase in the mean of the distribution (values ranging from $2.7^{\circ} \mathrm{C}$ in the $\mathrm{B} 2$ scenario to $4.0^{\circ} \mathrm{C}$ in the A2 scenario) similar to that found for summer.

When we analysed the results for the changes in the percentiles values for the past and future $T_{\min }$ distribution (Table 5) we found that, for winter, the highest changes occur in the lower percentiles (10 and 25), which is opposite to what was found for $T_{\text {max }}$. For the other seasons, the highest increases were found for the 90th percentile and for the A2 scenario. Also of interest is that the highest increases in temperature were observed for $T_{\max }$ unlike what was detected in the past climate, here the highest changes were found for $T_{\min }$.

When comparing the distributions obtained for the 1961-1990 and the 2071-2100 periods, one can expect changes in the frequencies of occurrence of tempera- ture extremes (Table 6). Assuming the same threshold values for the occurrence of extreme events in the future as those found for the 1961-1990 period (e.g. 10th and 90th seasonal percentile for $T_{\max }$ and $T_{\min }$ ), one can expect that the frequency of cold events almost disappears, whereas a significant increase in warm extreme events is expected. The highest decrease in cold extremes frequency are foreseen for the winter season, ranging from one-third to one-fifth less in $T_{\max }<T_{\max }$ seasonal 10th percentile and from onefifth to one-tenth less in the case of $T_{\min }<T_{\max }$ seasonal 10th percentile. For the extreme heat events, the highest increases were found for summer (3.69-fold) and winter (3.23-fold) in the case where $T_{\max }>T_{\max }$ seasonal 90th percentile for the A2 scenario. In the case of $T_{\min }>T_{\max }$ seasonal 90th percentile, the highest increases were found in summer and spring.

\section{DISCUSSION AND CONCLUSIONS}

An analysis of $T_{\max }, T_{\min }$ and $T_{\text {mean }}$ for western Iberia showed a decrease in temperature during the first subperiod of analysis (1945-1975) and an increase in temperature during the second sub-period (1976-2006), with higher changes recorded for $T_{\min }$ than for $T_{\max }$. The rise of $0.52^{\circ} \mathrm{C}$ decade ${ }^{-1}$ since 1976 in $T_{\text {mean }}$ was higher than the increases in $T_{\text {mean }}$ obtained for global land-only temperature trends described in IPCC (2007). 
Table 6. Ratio between the frequency of extreme events in future scenarios (according to the reference values for the occurrence of extreme events for the 1961-1990 period) and the frequency of extreme events in the control simulation for maximum and minimum temperature $\left(T_{\max }\right.$ and $T_{\min }$, respectively)

\begin{tabular}{|c|c|c|c|c|}
\hline \multicolumn{3}{|c|}{$T_{\max }>T_{\max }$ 90th percentile } & \multicolumn{2}{|c|}{$T_{\max }<T_{\max } 10$ th percentile } \\
\hline & B2 & A2 & B2 & A2 \\
\hline \multicolumn{5}{|l|}{$T_{\max }$} \\
\hline DJF & 2.68 & 3.23 & 0.33 & 0.19 \\
\hline MAM & 2.51 & 2.53 & 0.46 & 0.40 \\
\hline JJA & 2.79 & 3.69 & 0.53 & 0.36 \\
\hline SON & 2.05 & 2.71 & 0.44 & 0.30 \\
\hline \multicolumn{3}{|c|}{$T_{\min }>T_{\min }$ 90th percentile } & \multicolumn{2}{|c|}{$T_{\min }<T_{\min } 10$ th percentile } \\
\hline \multicolumn{5}{|l|}{$T_{\min }$} \\
\hline DJF & 1.94 & 2.45 & 0.19 & 0.10 \\
\hline MAM & 2.97 & 3.17 & 0.43 & 0.36 \\
\hline JJA & 2.60 & 3.63 & 0.29 & 0.14 \\
\hline SON & 2.62 & 2.52 & 0.37 & 0.20 \\
\hline
\end{tabular}

With the help of standardized temperature-related indices, a more in-depth evaluation of the observed changes in temperature extremes was performed for Portugal using the largest number of stations with long-term homogeneous data, allowing us to put these temperature trends into a wider spatial context.

Portugal experiences a relatively large number of heat wave events, with considerable impacts on ecosystems (e.g. wildfires and health, including excess mortality; Garcia et al. 1999, Paixão \& Nogueira 2003, Pereira et al. 2005, Trigo et al. 2009, García-Herrera et al. 2010). As such, it is of paramount importance to evaluate not only the changes in extreme temperature events in the recent climate, but also to study the potential increment in the likelihood of occurrence of extreme temperature events in the following decades.

Results show that there has been an increase since the mid-1970s in the number of days with maximum and/or minimum temperatures above the corresponding $90 \%$ threshold (i.e. TX90 and TN90) in summer. In addition, this was accompanied by a similar increase in the WSDI, which indicates a tendency towards a higher frequency of heat wave events. By contrast, the frequency of extreme cold-related events (TX10 and TN10) in Portugal decreased, with results being statistically significant for the majority of the weather stations in spring and summer and less significant in winter.

Most previous studies have focused mainly on the winter and summer seasons. However, both transition seasons (spring and autumn) are worth analysing. Beniston (2005) pointed out that the average maximum exceedance of $T_{\max }$ per decade in Switzerland is higher in winter than in the rest of the seasons. Moreover, Xoplaki et al. (2005) have shown, based on European temperature reconstructions for spring back to 1500 , that the decade 1995-2004 was very likely the warmest since the 16th century. Thus, we should also emphasise the widespread (and significant) increase in TX90 days in spring (Fig. 5) since the mid-1970s. Because this increase occurs in the season prior to summer, it is prone to have significant socio-economic effects, because of the exposure to higher temperatures sooner than is expected (García-Herrera et al. 2005). One can discuss if the warming in recent decades is due to anthropogenic forcing or natural variability. The last IPPC report (IPCC 2007, p. 665) stated that 'it is likely that there has been significant anthropogenic warming over the past 50 yr averaged over each continent except Antarctica.' A large number of studies (e.g. Tett et al. 2002, Jones et al. 2003, Stott et al. 2010) support the notion that recent warming is due to anthropogenic forcing.

In the second part of the present study we used the output of an RCM to study changes in the distributions of $T_{\max }$ and $T_{\min }$ and the associated changes in the likelihood of occurrence of extreme events in the future (2071-2100) under different climate change scenarios. In general, changes in future scenarios are in line with those found since the mid-1970s in Portugal, i.e. a mean increase in maximum temperature ranging from $3.2^{\circ} \mathrm{C}$ for the $\mathrm{B} 2$ scenario to $4.7^{\circ} \mathrm{C}$ for the A2 scenario in summer. It should be noted that the model foresaw an important increase in $T_{\max }$ in spring $\left(\sim 3.4^{\circ} \mathrm{C}\right)$ for both scenarios. For $T_{\min }$, the results are very similar, with increases in summer (spring) that range from $2.7^{\circ} \mathrm{C}$ $\left(2.5^{\circ} \mathrm{C}\right)$ for the $\mathrm{B} 2$ scenario to $4.1^{\circ} \mathrm{C}\left(2.9^{\circ} \mathrm{C}\right)$ for the $\mathrm{A} 2$ scenario.

When we analysed the distribution functions of $T_{\max }$ and $T_{\min }$, we found asymmetric increases in the different percentiles when comparing the control period and the future scenarios. In general, the highest changes in the percentiles were found for the 75th and 90th percentiles and the smallest changes were found for the 10 th percentile.

These changes in $T_{\max }$ and $T_{\min }$ in Portugal under future climate change scenarios were also characterised by changes in the occurrence of extreme events. Results show an increase in the frequency of hot extreme events are likely to occur, along with a decrease in the frequency of cold events.

Acknowledgements. The work was partly supported by the Portuguese Science Foundation (FCT) through project FLAIR (PTDC/AAC-AMB/104702/2008). R.M.T. received support from the EU 6th Framework Program (CIRCE) contract no. 36961 (GOCE). A.M.R. received a scholarship from the IMPACTE project (Gulbenkian Foundation project no 1568). The authors are also indebted to S. Cunha and Á. Silva from IM for their help in processing Figs. 1, 4, 5, 6 \& 7. Finally, the authors thank the reviewers for their constructive comments that helped to improve the manuscript. 


\section{LITERATURE CITED}

Aguilar E, Auer I, Brunet M, Peterson TC, Wieringa J (2003) Guidance on metadata and homogenization. WMO TD N. 1186 (WCDMP N. 53), World Meteorological Organization, Geneva

Alexander LV, Zhang X, Peterson TC, Caesar J and others (2006) Global observed changes in daily climate extremes of temperature and precipitation. J Geophys Res 111: D05109

> Alexandersson H (1986) A homogeneity test applied to precipitation data. J Climatol 6:661-675

> Alexandersson H, Moberg A (1997) Homogenization of Swedish temperature data. I. Homogeneity test for linear trends. Int J Climatol 17:25-34

Beniston M (2004) The 2003 heat wave in Europe: a shape of things to come? An analysis based on Swiss climatological data and model simulations. Geophys Res Lett 31:L02202 doi: 10.1029/2003GL018857

Beniston M (2005) Warm winter spells in the Swiss Alps: strong heat waves in a cold season? Geophys Res Lett 32: L01812 doi: 10.1029/2004GL021478

Beniston M, Stephenson DB, Christensen OB, Ferro CAT and others (2007) Future extreme events in European climate: an exploration of regional climate model projections. Clim Change 81:71-95

Brunet M, Jones PD, Sigro J, Saladie O and others (2007) Temporal and spatial temperature variability and change over Spain during 1850-2005. J Geophys Res 112:D12117 doi: 10.1029/JD008249

Buishand TA (1982) Some methods for testing the homogeneity of rainfall records. J Hydrol 58:11-27

Burt S (2004) The August 2003 heat wave in the United Kingdom. I. Maximum temperatures and historical precedents. Weather 59:199-208

Christensen JH, Christensen OB (2007) A summary of the PRUDENCE model projections of changes in European climate during this century. Clim Change 81(Suppl 1):7-30

> Christensen JH, Machenhauer B, Jones RG, Schar C, Ruti PM, Castro M, Visconti G (1997) Validation of present-day regional climate simulations over Europe: LAM simulations with observed boundary conditions. Clim Dyn 13: 489-506

- Clark R, Brown S, Murphy J (2006) Modelling Northern Hemisphere summer heat extreme changes and their uncertainties using a physics ensemble of climate sensitivity experiments. J Clim 19:4418-4435

Della-Marta PM, Luterbacher J, von Weissenfluh H, Xoplaki E, Brunet M, Wanner H (2007) Summer heat waves over western Europe 1880-2003, their relationship to largescale forcings and predictability. Clim Dyn 29:251-275

> Dessai S (2002) Heat stress and mortality in Lisbon. I. Model construction and validation. Int J Biometeorol 47:6-12

Díaz J, López C, Alberdi JC, Jordán A, García R, Hernández E, Otero A (2002a) Heat waves in Madrid 1986-1997: effects on the health of the elderly. Int Arch Occup Environ Health 75:163-170

> Díaz J, García R, Velásquez de Castro F, Hernández E, López C, Otero A (2002b) Effects of extremely hot days on people older than 65 years in Seville (Spain) from 1986 to 1997. Int J Biometeorol 46:145-149

> Díaz J, García-Herrera R, Trigo RM, Linares C, Valente MA, De Miguel JM, Hernández E (2006) The impact of summer 2003 heat wave in Iberia: How should we measure it? Int J Biometeorol 50:159-166

Frich P, Alexander LV, Della-Marta P, Gleason B, Haylock M, Klein Tank AMG, Peterson T (2002) Observed coherent changes in climatic extremes during the second half of the twentieth century. Clim Res 19:193-212

Garcia AC, Nogueira PJ, Falcão JM (1999) Onda de calor de Junho de 1981 em Portugal: efeitos na mortalidade. Rev Port Saúde Pública Vol Temático I:67-77

> García-Herrera R, Díaz J, Trigo RM, Hernandez E (2005) Extreme summer temperatures in Iberia: health impacts and associated synoptic conditions. Ann Geophys 23: 239-251

García-Herrera R, Díaz J, Trigo RM, Luterbacher J, Ficher E (2010) A review of the European summer heat wave of 2003. Crit Rev Environ Sci Technol 40:267-306

Hageman S, Botzet M, Machenhauer B (2001) The summer drying problem over south-eastern Europe: sensitivity of the limited area model HIRHAM4 to improvements in physical parameterization and resolution. Phys Chem Earth B 26:391-396

Heino R, Brázdil R, Forland E, Tuomenvirta H and others (1999) Progress in study of climatic extremes in northern and central Europe. Clim Change 42:151-181

IPCC (2007) Climate change 2007: the physical science basis. In: Solomon S, Qin D, Manning M, Chen Z and others (eds) Contribution of Working Group I to the Fourth Assessment Report of the Intergovernmental Panel on Climate Change. Cambridge University Press, Cambridge

INVS (Institut De Veille Sanitaire) (2003) Impact sanitaire de la vague de chaleur en France survenue en aout 2003 Rapport d'étape-29 aout 2003. Institut De Veille Sanitaire, Saint Maurice, France

> Jacob D, and others (2007) An inter-comparison of regional climate models for Europe: model performance in presentday climate. Clim Change 81(Suppl 1):31-52

Jones PD, New M, Parker DE, Martin S, Rigor IG (1999) Surface air temperature and its changes over the past 150 years. Rev Geophys 37:173-199

Jones GS, Tett SFB, Stott A (2003) Causes of atmospheric temperature change 1960-2000: a combined attribution analysis. Geophys Res Lett 30:1228 doi:10.1029/2002GL0 16377

Karl TR, Nicholls N, Gregory J (1997) The coming climate. Sci Am May 1997:54-59

Karl TR, Knight RW, Baker B (2000) The record breaking global temperature of 1997 and 1998: evidence for an increase in rate of global warming? Geophys Res Lett 27 : 719-722

> Klein Tank AMG, Wijngaard JB, Können GP, Böhm R and others (2002) Daily dataset of 20th-century surface air temperature and precipitation series for the European Climate Assessment. Int J Climatol 22:1441-1453 doi: 10.1002/joc.773

> Klein Tank AMG, Können GP (2003) Trends in indices of daily temperature and precipitation extremes in Europe, 1946-99. J Clim 16:3665-3680

Klein Tank AMG, Zwiers FW, Zhang X (2009) Guideline on analysis of extremes in a changing climate in support of informed decisions for adaptation. Climate Data and Monitoring WCDMP-No. 72, WMO-TD No. 1500, Geneva, Switzerland

Manton MJ, and others (2001) Trends in extreme daily rainfall and temperature in Southeast Asia and the South Pacific: 1916-1998. Int J Climatol 21:269-284

Moberg A, and others (2006) Indices for daily temperature and precipitation extremes in Europe analysed for the period 1901-2000. J Geophys Res 111:D22106 doi:10.1029/ 2006JD007103

> Moberg A, Jones P (2004) Regional climate model simulations of daily maximum and minimum near surface tempera- 
tures across Europe compared with observed station data 1961-1990. Clim Dyn 23:695-715

Moberg A, Jones PD, Barriendos M, Bergström H and others (2000) Day-to-day temperature variability trends in 160- to 275-year-long European instrumental records. J Geophys Res 105:22849-22868

Munich Re (2004) TOPICS Geo 2003. Munchener Ruckversicherungs-Gesellschaft, Munich

Nakicenovic N, Swart R (2000) Special report on emissions scenarios. A Special Report of Working Group III of the Intergovernmental Panel on Climate Change. Cambridge University Press, Cambridge

Nicholls N, Murray W (1999) Precipitation. Breakout group B. Workshop on indices and indicators for climate extremes, Asheville, NC, USA, 3-6 June 1997. Clim Change 42:23-29

> Noguer M, Jones R, Murphy J (1998) Sources of systematic errors in the climatology of a regional climate model over Europe. Clim Dyn 14:691-712

Paixão EJ, Nogueira PJ (2003) Efeitos de uma onda de calor na mortalidade. Rev Port Saude Publica 21:41-54

> Pereira MG, Trigo RM, da Camara CC, Pereira JMC, Leite SM (2005) Synoptic patterns associated with large summer forest fires in Portugal. Agric For Meteorol 129:11-25

Peterson TC, Folland C, Gruza G, Hogg W, Abdallah M, Plummer N (2001) Report on the activities of the working group on climate change detection and related rapporteurs. ICPO Publication Series no. 48, World Meteorological Organization, Geneva

Pope VD, Gallani M, Rowntree PR, Stratton RA (2000) The impact of new physical parametrizations in the Hadley Centre climate model-HadAM3. Clim Dyn 16:123-146

Santos FD, Miranda P (eds) (2006) Alterações climáticas em Portugal: cenários, impactos e medidas de adaptação. Gradiva, Lisboa

Santos FD, Forbes K, Moita R (eds) (2002) Climate change in Portugal: scenarios, impacts and adaptation measures. Gradiva, Lisboa

Santos JA, Corte-Real J (2006) Temperature extremes in Europe and wintertime large-scale atmospheric circulation: HadCM3 future scenarios. Clim Res 31:3-18

Santos JA, Leite S (2009) Long-term variability of the temperature time series recorded at Lisbon. J Appl Stat 36: 323-337

Schär C, Vidale PL, Lüthi D, Häberli C, Liniger MA, Appenzeller C (2004) The role of increasing temperature variability in Europe summer heatwaves. Nature 427:332-336

Stott PA, Gillett NP, Hegerl GC, Karoly DJ, Stone DA, Zhang X, Zwiers F (2010) Detection and attribution of climate change: a regional perspective. Wiley Interdisciplinary Reviews: Clim Change 1:192-211

Submitted: March 12, 2010; Accepted: September 8, 2010
Tebaldi C, Hayhoe K, Arblaster JM, Meehl GE (2006) Going to the extremes: an intercomparison of model-simulated historical and future changes in extreme events. Clim Change 79:185-211

Tett SFB, Jones GS, Stott PA, Hill DC and others (2002) Estimation of natural and anthropogenic contributions to twentieth century temperature change. J Geophys Res 107: 4306 doi:10.1029/2000JD000028

Tomé AR, Miranda PMA (2004) Piecewise linear fitting and trend changing points of climate parameters. Geophys Res Lett 31:L02207 doi:10.1029/2003GL019100

- Trigo RM, García-Herrera R, Díaz J, Trigo IF, Valente MA (2005) How exceptional was the early August 2003 heatwave in France? Geophys Res Lett 32:L10701 doi:10.1029/ 2005GL022410

> Trigo RM, Pereira JMC, Pereira MG, Mota B, Calado MT, DaCamara CC, Santo FE (2006) The exceptional fire season of summer 2003 in Portugal. Int J Climatol 26: 1741-1757

> Trigo RM, Ramos AM, Nogueira PJ, Santos FD, GarciaHerrera R, Gouveia C, Santo FE (2009) Evaluating the impact of extreme temperature based indices in the 2003 heatwave excessive mortality in Portugal. Environ Sci Policy 12:844-854

Tuomenvirta H (2000) Homogeneity testing and analysis of climatological time series from Finland and the Nordic region. Licenciate thesis, University of Helsinki, Department of Meteorology

von Neumann J (1941) Distribution of the ratio of the mean square successive difference to the variance. Ann Math Stat 12:367-395

> Vose RS, Easterling DR, Gleason B (2005) Maximum and minimum temperature trends for the globe: an update through 2004. Geophys Res Lett 32:L23822 doi:10.1029/ 2005GL024379

> Wang XL (2008a) Accounting for autocorrelation in detecting mean-shifts in climate data series using the penalized maximal $t$ or $F$ test. J Appl Meteorol Climatol 47:2423-2444

> Wang XL (2008b) Penalized maximal F-test for detecting undocumented mean-shifts without trend-change. J Atmos Ocean Technol 25:368-384

> Wang XL, Wen QH, Wu Y (2007) Penalized maximal $t$ test for detecting undocumented mean change in climate data series. J Appl Meteorol Climatol 46:916-931 doi:10.1175/ JAM2504.1

> Xoplaki E, Luterbacher J, Paeth H, Dietrich D, Steiner N, Grosjean M, Wanner H (2005) European spring and autumn temperature variability and change of extremes over the last half millennium. Geophys Res Lett 32:L15713 doi:10.1029/2005GL023424

Proofs received from author(s): April 14, 2011 